\title{
BCL2 and miR-181a transcriptional alterations in umbilical-cord blood cells can be putative biomarkers for obesity
}

\author{
João Paulo de Castro Marcondes ${ }^{\mathrm{a}, \mathrm{b}, *}$, Pablo Felipe Bertolini Andrade ${ }^{\mathrm{a}}$, André Luiz Ventura Sávio ${ }^{\mathrm{a}}$, \\ Maruhen Amir Datsch Silveira ${ }^{\mathrm{a}}$, Marilza Vieira Cunha Rudge ${ }^{\mathrm{a}}$, Daisy Maria Fávero Salvadori ${ }^{\mathrm{a}}$ \\ ${ }^{\text {a } U N E S P ~-~ S a ̃ o ~ P a u l o ~ S t a t e ~ U n i v e r s i t y, ~ M e d i c a l ~ S c h o o l, ~ B o t u c a t u, ~ S P, ~ B r a z i l ~}$ \\ ${ }^{\mathrm{b}}$ UNESP - São Paulo State University, Bioscience Institute, Botucatu, SP, Brazil
}

\section{A R T I C L E I N F O}

\section{Keywords:}

Gestational diabetes mellitus

Fetal programming

Hyperglycemia

Telomere length

\begin{abstract}
A B S T R A C T
Several findings suggest that in utero stressor stimuli can alter fetal development by promoting transcriptional changes, and predisposing the neonate to diseases later in life. This study aimed to investigate whether a hyperglycemic environment in pregnant women with gestational diabetes mellitus (GDM) is able to cause fetal genetic alterations and predispose neonates to obesity. Transcriptional alteration of SIRT1, TP53 and BCL2 genes, miR-181a (a SIRT1 or BCL2 regulator) and telomere length were evaluated in placental and umbilical-cord blood cells. Healthy (HP; $n=20)$ and GDM $(n=20)$ pregnant women and their respective neonates were included in the study. Additionally, obese $(n=20)$ and eutrophic $(n=20)$ adults also participated as reference populations. Gene expression data showed down-regulation of BCL2 in umbilical-cord and peripheral blood cells from GDM neonates and obese adults, respectively. The miR-181a was down-regulated only in umbilical-cord blood cells of GDM neonates. Telomere length presented no significant difference. In conclusion, our study demonstrated that the GDM hyperglycemic intrauterine environment promotes transcriptional alterations in BCL2 and miR-181a in neonate umbilical-cord blood cells. Furthermore, both GDM neonates and obese subjects share the same transcriptional alteration in $B C L 2$. Considering the relationship between obesity development and the functions regulated by these two genes, $B C L 2$ and miR-181a could be adopted as potential biomarkers for childhood obesity. However, further study designs are recommended to confirm this hypothesis.
\end{abstract}

\section{Introduction}

Obesity is a multifactorial disease based on both genetic and behavioral factors that may impair health, given its association with a range of cardio-metabolic diseases and cancer [1]. The worldwide obesity prevalence data show that about $13 \%$ of the adult population were obese in 2014 and approximately 41 million children under 5 years were overweight or obese [2]. Since childhood obesity prevalence has tripled over the last three decades, studies related to pediatric obesity have been rapidly increasing [3].

Compelling evidence has suggested that stressor factors, such as nutritional fluctuations and hyperglycemic environment during gestation can alter the developing fetus and impact offspring health by predisposing to type 2 diabetes mellitus, cardiovascular diseases and obesity in later life [4]. Indeed, a range of studies conducted in humans and non-human primates suggest that maternal nutrition affects the placenta and fetal tissues, leading to persistent changes in hepatic metabolism, mitochondrial function, intestinal microbiota, liver macrophage activation and susceptibility to nonalcoholic steatohepatitis postnatally [5]. However, the molecular mechanisms linking in utero stressors and increased risk for obesity during childhood and adulthood are poorly understood. Recent studies have shown that in utero stressors, such as obesity and/or gestational diabetes mellitus (GDM), besides promoting mitochondrial dysfunction might alter telomere homeostasis, thus increasing offspring risk for cardio-metabolic diseases [6-8]. In fact, the hyperglycemic intrauterine environment can induce persistent deficits in redox signaling that lead to mitochondrial dysfunction and increased in utero superoxide production, with subsequent activation of pathways involved in the pathogenesis of diabetes complications, increased formation of AGEs (advanced glycation end products) and activation of protein kinase $\mathrm{C}$ isoforms and proinflammatory genes $[9,10]$. On the other hand, in utero hyperglycemiarelated telomere shortening may induce senescence and, consequently, early onset of and age-related diseases [8].

SIRT1 is an important determinant of human longevity and a positive regulator of telomere length through modulation of telomerase

\footnotetext{
* Corresponding author at: São Paulo State University (UNESP), Botucatu Medical School, Department of Pathology; Rubião Jr, 18.618-970, Botucatu, SP, Brazil.

E-mail address: jpcastromarcondes@gmail.com (J.P.d.C. Marcondes).
} 
activity and homologous recombination repair [11]. Decreased expression was detected in fetal endothelial colony-forming cells from pregnancies complicated by GDM, and provided potential mechanistic insights into the pathophysiology of long-term cardiovascular complications observed in the offspring of GDM pregnancies [12]. Indeed, some studies have associated (sub)telomere maintenance and also mitochondrial biogenesis with SIRT1 and TP53 [13-16]. Furthermore, $B C L 2$ and other genes belonging to the $B C L 2$ family may also impact mitochondrial physiology through the regulation of autophagy, fusion/ fission process, and by exerting a glutathione-dependent antioxidant activity [17-21].

MicroRNAs (miRNAs) have been implicated in numerous biological processes, including cell proliferation, cell death, cell differentiation, tumorigenesis and lipid metabolism [22,23]. It has been suggested that $m i R-181 a$ plays a role in the link between adipose tissue dysfunction and the development of obesity-associated disorders including type 2 diabetes, with significant correlations between its expression and both adipose tissue morphology and key metabolic parameters, including visceral fat area, HbA1c, fasting plasma glucose and circulating leptin, adiponectin and interleukin-6 [24]. Moreover, evidence suggests that $m i R-181 a$ can regulate the hepatic insulin sensitivity, lipolysis, senescence and mitochondrial function through modulation of SIRT1 and BCL2 mRNA levels [25-27].

The aim of the present study was to investigate whether the hyperglycemic in utero environment in gestational diabetes mellitus (GDM) patients promotes telomere shortening, transcriptional modulation of SIRT1, TP53, BCL2 and miR-181a, and whether such alterations are present in obese adults.

\section{Material and methods}

\subsection{Study population}

This study was approved by the Ethics Committee for Human Research from the UNESP Medical School (Protocol number 14489013.0.0000.5411). All participants signed the terms of informed consent before being included in the study. GDM patients (Group 1; $\mathrm{n}=20$ ) and their respective neonates (Group 2) were recruited at the Clinical Hospital (Botucatu, SP, Brazil), and healthy pregnant women (HP) (Group 3, control; $\mathrm{n}=20$ ) and their respective neonates (Group 4), at the Unimed Hospital (Botucatu, SP, Brazil). Twenty obese (BMI $\geq 30 \mathrm{~kg} / \mathrm{m}^{2}$; Group 5) and 20 eutrophic (BMI ranging from 18 to $24.9 \mathrm{~kg} / \mathrm{m}^{2}$; Group 6) male and female adults were recruited as control groups (Table 1). The adult population was recruited according to the gender of neonates.

The pre-pregnancy weight before conception was obtained by selfreports at the time of the first prenatal visit, or during the Informed Consent application process. GDM was diagnosed according to the criteria of the American Diabetes Association [28], and the recommendation of Rudge et al. [29]. Briefly, glucose tolerance was assessed using a $2 \mathrm{~h}(75 \mathrm{~g})$ oral glucose tolerance test (OGTT) performed between the 24th and 28th weeks of pregnancy. Blood samples were collected during fasting (fasting glucose levels) and at $1 \mathrm{~h}$ and $2 \mathrm{~h}$ after standard dextrose. Gestational diabetes mellitus was confirmed when glucose reached or exceeded the maximum values: $\geq 92 \mathrm{mg} / \mathrm{dL}$ for fasting, $\geq 180 \mathrm{mg} / \mathrm{dL}$ for $1 \mathrm{~h}$-OGTT, and $\geq 153 \mathrm{mg} / \mathrm{dL}$ for $2 \mathrm{~h}$-OGTT. The treatment of the GDM pregnant women (insulin administration when diet and exercise were not effective for glycemic control) started immediately after diagnosis. Neonates were classified as either appropriate for gestational age (AGA), small for gestational age (SGA), or large for gestational age (LGA), according to the growth curve proposed by Battaglia and Lubchenco [30]. The Apgar 1 min score (how the baby tolerates the birthing process) was also determined. Volunteers who had taken regular medication (except women who regularly used contraceptives) and/or those with chronic diseases were excluded from the study. In the eutrophic group, only subjects with no familial (father, mother or siblings) history of chronic diseases were included. The study population was also distributed according to smoking habits: smokers were defined as those who had smoked at least 100 cigarettes in their whole life or were currently smokers (every day or sporadically); exsmokers, those that stopped smoking at least one year before [31]. Alcohol consumption was classified into three categories: non-consumers; social drinkers (consumption up to a $\sim 3.4 \mathrm{fl}$. oz. glass of alcoholic beverage per day or at weekends; and heavy drinkers, those who consumed more than $1 \mathrm{~L}$ of light alcoholic beverage (beer, wine or cider) or two glasses of hard liquor (Brazilian cachaça, rum, vodka, or whisky) per day, for at least 6 years. Subjects were defined as being "exposed to toxic substances" (pesticides, solvents, diesel exhaust, dyes etc.) if they reported a history of occupational exposure or had been recently exposed to toxic substances [32] (Table 1).

\subsection{Blood and placenta cell sampling}

After delivery, the placenta was collected and conditioned in a cooler containing sterile cold $0.9 \%$ saline solution. The chorionic plate and overlying membranes were removed, and anatomically healthy fragments of approximately $0.5 \mathrm{~cm}^{3}$ were obtained from maternal (decidua) and fetal (villous) surfaces. The fragments were placed into cryogenic vials containing RNAlater (Life Technologies, USA) and kept at $4{ }^{\circ} \mathrm{C}$ overnight. After RNAlater removal, the fragments were stored at $-80^{\circ} \mathrm{C}$ for further total RNA extraction. Umbilical-cord and peripheral blood samples $(5 \mathrm{~mL})$ were collected from neonates and obese/eutrophic adults, respectively, and placed into PAXgene Blood RNA Tubes (PreAnalytiX, Switzerland) for total RNA and microRNA extraction. Blood samples $(1 \mathrm{~mL})$ collected in Vacutainer ${ }^{\circledast} \mathrm{K}_{2}$ EDTA tubes (BD, USA) were placed into microtubes and stored at $-80^{\circ} \mathrm{C}$ for genomic DNA extraction

\subsection{RNA, microRNA and DNA extraction}

Total RNA and microRNA were extracted from placental (fetal and maternal surfaces) and whole blood (peripheral and umbilical-cord)

Table 1

General characteristics of the study population.

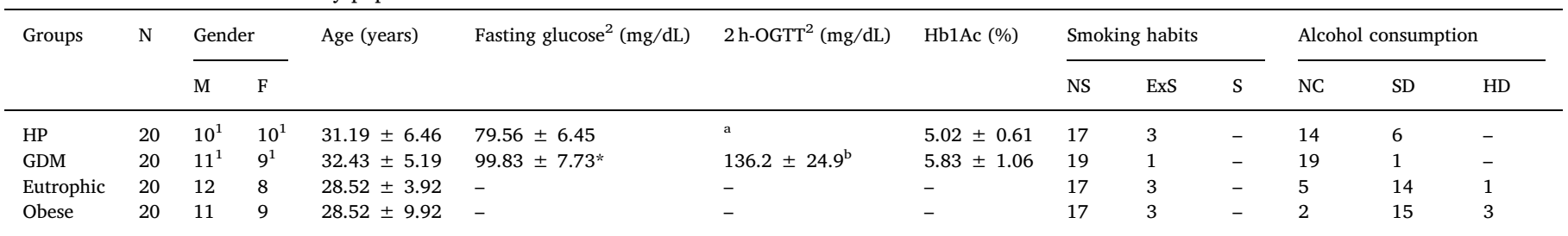

HP: healthy pregnant women; GDM: women with gestational diabetes mellitus; M: male; F: female; OGTT: oral glucose tolerance test ( $75 \mathrm{~g}) ;{ }^{1}$ neonate; ${ }^{2}$ measurements at 24 to $28^{\text {th }}$ gestational week; ${ }^{a}$ it was not quantified; ${ }^{b}$ the maximum reference value for GDM is $153 \mathrm{mg} / \mathrm{dL}$;Hb1Ac: glycated hemoglobin; NS: non-smoker; ExS: exsmoker; S: smoker; NC: non-consumer; SD: social drinker; HD: heavy drinker. *p $<0.05$ compared to the healthy pregnant women. Data are expressed mean \pm standard deviation. 
Table 2

Anthropometric and delivery characteristics of the study population.

\begin{tabular}{|c|c|c|c|c|c|c|c|c|c|c|c|c|c|}
\hline \multirow[t]{2}{*}{ Groups } & \multirow[t]{2}{*}{$\mathrm{N}$} & \multicolumn{2}{|c|}{ Gender } & \multirow[t]{2}{*}{ Initial $\mathrm{BMI}^{2}\left(\mathrm{~kg} / \mathrm{m}^{2)}\right.$} & \multirow{2}{*}{$\begin{array}{l}\text { Final } \mathrm{BMI}^{3}(\mathrm{~kg} / \\
\mathrm{m}^{2)}\end{array}$} & \multirow{2}{*}{$\begin{array}{l}\text { Weight gain in } \\
\text { pregnancy }\end{array}$} & \multicolumn{2}{|c|}{ Delivery } & \multirow[t]{2}{*}{ Neonateweight $(\mathrm{kg})$} & \multirow[t]{2}{*}{ Apgar1' score ${ }^{4}$} & \multicolumn{3}{|c|}{ Neonate classification } \\
\hline & & M & $\mathrm{F}$ & & & & $\mathrm{V}$ & $\mathrm{C}$ & & & LGA & AGA & SGA \\
\hline HP & 20 & $10^{1}$ & $10^{1}$ & $23.2 \pm 1.3$ & $28.8 \pm 2.5$ & $13.2 \pm 6.3$ & - & 20 & $3.3 \pm 0.4$ & $9.0 \pm 0.7$ & 1 & 19 & - \\
\hline GDM & 20 & $11^{1}$ & $9^{1}$ & $31.9 \pm 6.9 *$ & $35.5 \pm 4.8^{*}$ & $9.2 \pm 6.8$ & 2 & 18 & $3.4 \pm 0.6$ & $8.3 \pm 0.7$ & 4 & 16 & - \\
\hline Eutrophic & 20 & 12 & 8 & $21.7 \pm 1.8$ & - & - & - & - & - & - & - & - & - \\
\hline Obese & 20 & 11 & 9 & $34.7 \pm 5.8^{* *}$ & - & - & - & - & - & - & - & - & - \\
\hline
\end{tabular}

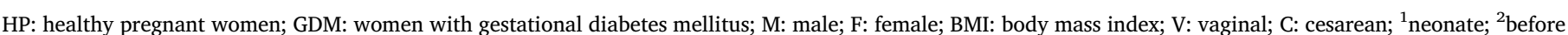

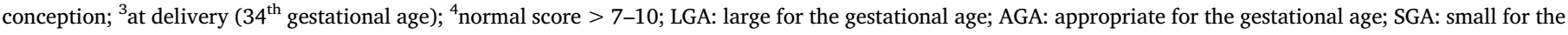

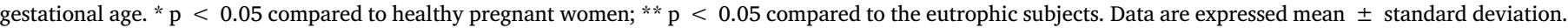

cells using the PAXgene Blood RNA and PAXgene Blood microRNA kits (PreAnalytiX, Switzerland), respectively. Genomic DNA was extracted using the Illustra blood genomic Prep Mini Spin kit (GE Healthcare, UK). RNA samples were quantified in a NanoDrop One spectrophotometer (Thermo Scientific, USA), and quality/integrity was checked in a 2100 Bioanalyzer (Agilent, USA). Genomic DNA samples were quantified by the Pico-Green method using a 96-well spectrophotometer (Molecular Devices, USA); integrity was checked using $1.5 \%$ agarose gel.

\subsection{SIRT1, TP53, BCL2 and miR-181a relative expression}

The mRNAs and microRNAs were reverse-transcribed to cDNA using the High Capacity cDNA Reverse Transcription kit and TaqMan $^{\circledR}$ MicroRNA reverse transcription kit (Applied Biosystems, USA), respectively, according manufacturer's instructions. The cDNA was used as a template for quantitative real-time PCR (qPCR), with specific human primers (Taqman ${ }^{\circledR}$ system - Applied Biosystems, Foster City, CA, USA) for SIRT1 (Hs01009005_m1), TP53 (Hs99999147_m1), BCL2(Hs00608023_m1) and hsa-miR-181a (000480). For gene expression, each tube contained $2 \mu \mathrm{L}$ of cDNA template, $5 \mu \mathrm{L}$ of TaqMan ${ }^{\circledast}$ Fast Universal PCR Master Mix (2x) (Applied Biosystems), $0.5 \mu \mathrm{L}$ of TaqMan $^{\circledR}$ Gene Expression assay (20X) (Applied Biosystems) and $2.5 \mu \mathrm{L}$ of nuclease-free water. For microRNA expression, each tube contained $1.33 \mu \mathrm{L}$ of cDNA template, $10 \mu \mathrm{L}$ of TaqMan $^{\circledR}$ Universal PCR Master Mix II with UNG (2X), $1 \mu \mathrm{L}$ of TaqMan ${ }^{\circledR}$ Small RNA Assay (20X) and $7.67 \mu \mathrm{L}$ of nuclease-free water. The reaction was performed using the following thermal cycling conditions: $94^{\circ} \mathrm{C}$ for $10 \mathrm{~min}$, followed by 40 cycles of $94^{\circ} \mathrm{C}$ for $30 \mathrm{~s}$ and $60^{\circ} \mathrm{C}$ for $1 \mathrm{~min}$ (gene expression); and $50^{\circ} \mathrm{C}$ for $2 \mathrm{~min}$ and $95^{\circ} \mathrm{C}$ for $10 \mathrm{~min}$, followed by 40 cycles of $95^{\circ} \mathrm{C}$ for $15 \mathrm{~s}$ and $60^{\circ} \mathrm{C}$ for $1 \mathrm{~min}$ (microRNA expression). Fluorescence data were collected during each annealing/extension step. Gene and microRNA data were normalized to ACTB gene (Hs99999903_m1) and snoRNA RNU6B (001093), respectively. The real-time PCR assays were performed in triplicate and analysis was performed using the comparative delta-delta Ct method $(\Delta \Delta \mathrm{Ct})[33]$.

\subsection{Telomere length assay}

Relative telomere length was measured using the genomic DNA extracted from peripheral and umbilical-cord blood cells. The qPCR was run on the $7900 \mathrm{H}$ T Sequence Detection System (Applied Biosystems, USA). The ratio of the telomere repeat copy number to a single gene (36B4) copy number (T:S) was determined as previously described by Cawthon et al. [34]. The assays were performed in triplicate, and relative telomere length was the exponential ratio of telomere copy number to $36 B 4$ copy number corrected for a reference sample. The coefficients of variation (CVs) for the telomere assay and 36B4 assay were in the range from 0.84 to $0.92 \%$ and 0.36 to $0.54 \%$, respectively. The average of CVs for the exponential T:S of quality control samples was $12.78 \%$.

\subsection{Statistical analysis}

Shapiro-Wilk and Chi-square tests were used for analyzing data and gender distribution, respectively. Gene/micro-RNA expression and relative telomere length were analyzed using the one-way ANOVA followed by the post-hoc Tukey test. qPCR analysis was adjusted for possible confounding factors such as age, sex, alcohol consumption, and cigarette smoking. The Pearson correlation was performed to detect possible effects of glycemic (mother) and insulin levels (neonate) on telomere length. All analyses were performed using the software SAS for Windows (v.9.2), and any $\mathrm{p}$ value $<0.05$ was considered significant.

\section{Results}

Despite rigorous glycemic control, the fasting glucose levels were significantly higher in GDM patients than in healthy pregnant women (Table 1). BMI differed significantly between GDM and HP women $(31.9 \pm 6.9$ vs $23.2 \pm 1.3, \mathrm{p}<0.01)$ just before delivery, and also between obese and eutrophic adult subjects $(34.7 \pm 5.8$ vs. $21.7 \pm 1.8 ; \mathrm{p}<0.01)$. No differences were detected in the neonate weights and for maternal weight gain during pregnancy (Table 2). In relation to gene expression, BCL2 downregulation was detected in umbilical-cord blood cells from GDM neonates and in peripheral blood cells from adult obese subjects (Fig. 1). No modulation was detected in villous and decidua from diabetic patients. The miR-181a was downregulated in umbilical-cord blood cells of newborns from GDM women in relation to newborns from HP women (Fig. 2). No change was detected in placenta cells (villous and decidua) from GDM patients and in obese peripheral blood cells in relation to HP women and normal weight adults, respectively (Fig. 2). Similarly, no changes occurred in SIRT1 or TP53 or in telomere length in all tissues investigated (Figs. 1 and 3). A slight (but not statistically significant; $p=0.2791$ ) telomere shortening was observed in umbilical-cord blood cells from GDM neonates in relation to HP neonates. No significant correlation (Pearson's test) was detected between telomere length and fasting glucose levels $(\mathrm{R}=-0.09555 ; \mathrm{p}=0.768), \% \operatorname{HbA1C}(\mathrm{R}=0.2425 ; \mathrm{p}=0.348)$, or umbilical-cord blood insulin levels $(R=0.2251 ; p=0.4819)$ (Fig. 4).

\section{Discussion}

Adverse events during gestation have been described as inducing fetal programming, which can result in chronic diseases [35]. GDM has been associated with cardiovascular disease, metabolic syndrome, and obesity during later life in the offspring $[36,37]$. However, the pathophysiological mechanisms responsible for these late complications remain unknown. Herein, we evaluated whether intrauterine hyperglycemic environment was able to promote genetic alterations in placental and blood cells, and if those changes could be putative biomarkers for developing obesity in adulthood. The literature has reported that hyperglycemia may promote placental morphofunctional changes that can be associated with fetal macrosomia $[38,39]$. Furthermore, alterations 
A)

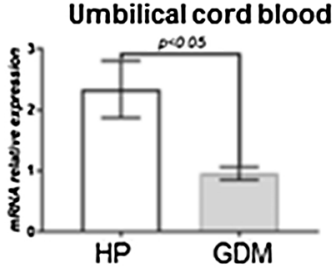

B)

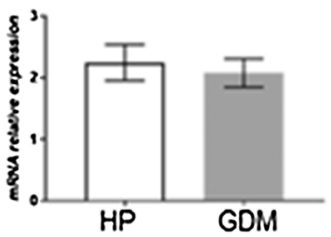

C)

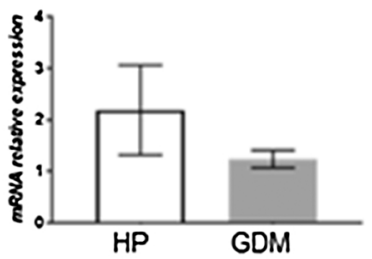

$B C L 2$
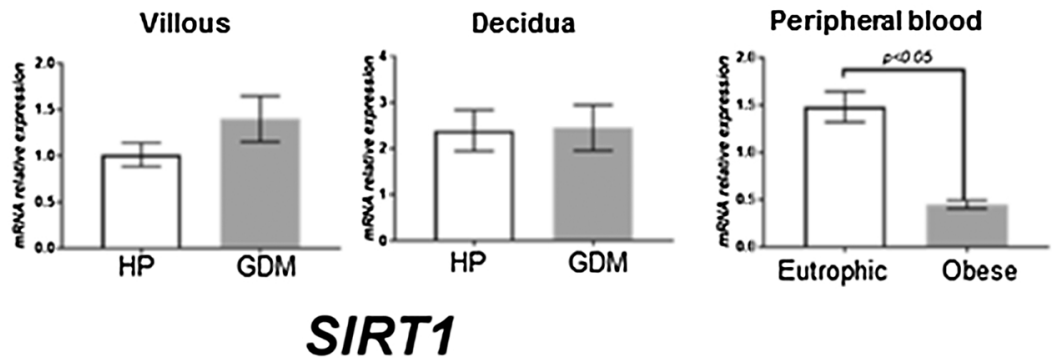

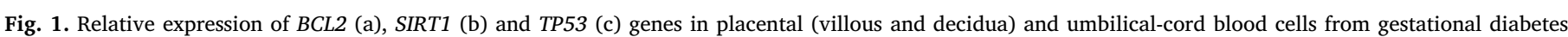

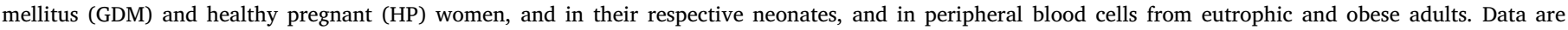
expressed as mean \pm standard deviation.

in early growth phenotypes resulting from an adverse in utero environment in association with a genetic background that increased the risk for adult cardiometabolic diseases have been also reported [40]. Although our data showed no difference in the weights of neonates from GDM, the prevalence of macrosomia or high prenatal growth rate (LGA) was similar to that reported in the literature (20-30\%) [41]. Macrosomia and LGA are considered markers of altered fetal programming that may increase the risk for future chronic complications of potentially greater relevance, such as childhood obesity, diabetes, metabolic syndrome, hypertension and cardiovascular morbidity [42]. In 2012, a prospective population-based cohort study (21,315 subjects) showed that at the age of 7 years, macrosomic infants had 1.52-fold and 1.50-fold greater risks of developing overweight or obesity, respectively [43].

Recently, Landon et al. [44], in a follow-up study of 500 children, observed that GDM treatment improved neonatal health, but the frequency of obesity or metabolic dysfunction at ages 5-10 years was not reduced. A meta-analysis study corroborated these findings showing no association between intensive gestational glycemic management and reduction of childhood obesity in offspring [45]. We observed that although fasting glucose levels was above the ADA's recommended levels [28], it was not sufficient to increase the percentage of Hb1Ac, demonstrating an efficient glycemic control. Moreover, the glycemic levels after $2 \mathrm{~h}$ of OGTT were below the ADA's recommendation.

Gestational diabetes mellitus is associated with alterations in telomere and mitochondrial homeostasis that can impair fetal development, predisposing the offspring to cardiometabolic diseases and obesity in later life $[6-8,10]$. It is well known that telomere length can be modulated by a variety of intrinsic and environmental factors throughout life. Beyond that, it has been reported that telomere shortening is associated with a series of metabolic abnormalities including impaired glucose tolerance, dyslipidemia, obesity, diabetes and cardiovascular diseases $[6,46]$. In contrast, our study did not show any significant telomere changes between eutrophic and obese adults or
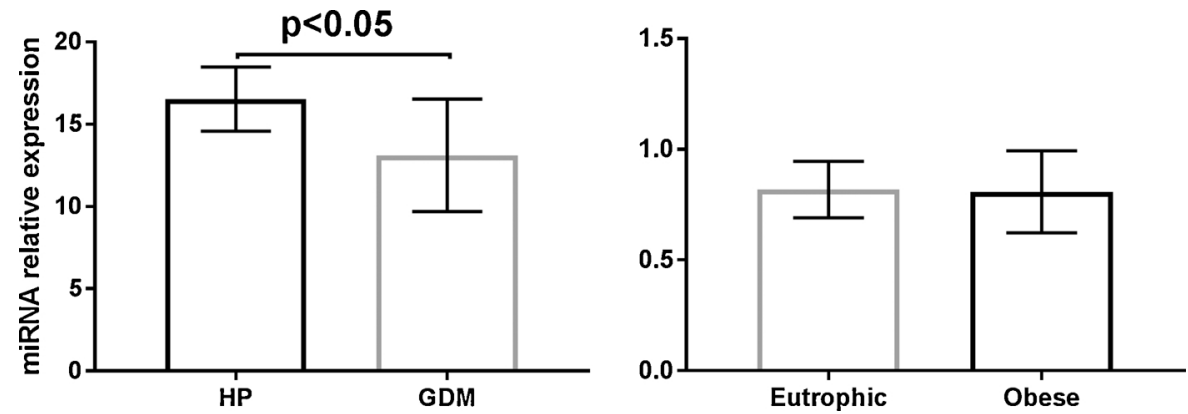

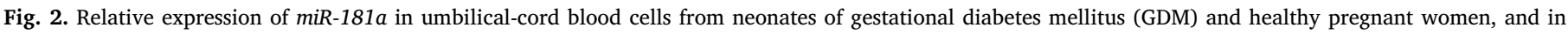
peripheral blood cells from eutrophic and obese adults. Data are expressed as mean \pm standard deviation. 


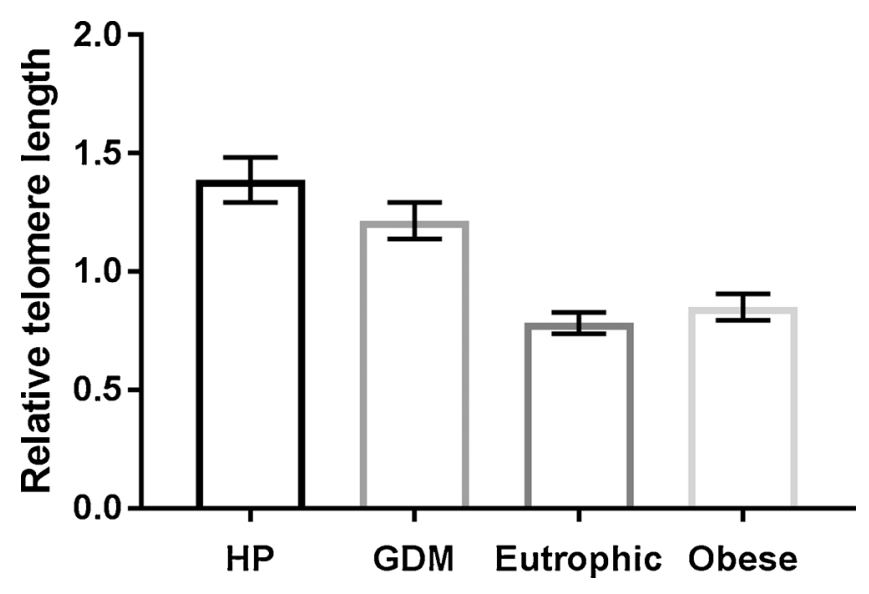

Fig. 3. Relative telomere length in umbilical-cord blood cells of gestational diabetes mellitus (GDM) and healthy pregnant (HP) women neonates and in peripheral blood cells of eutrophic and obese adults. Data are expressed as mean \pm standard deviation.

between the neonates of GDM and health pregnant women.

Data in literature are inconclusive about the effect of GDM and obesity on telomere shortening. Xu et al. [6] observed telomere shortening in neonates from GDM women. Contrarily, Gilfillan et al. [47] detected no effect of GDM or pre-gestational diabetes on telomere length, but found that the maternal and fetal glucose levels were negatively correlated with telomere length, possibly due to oxidative stress. Similarly, no effect from GDM and types 1 and 2 diabetes mellitus on telomere length in neonate umbilical-cord blood cells was reported by Cross et al. [48]. However, this latter study found higher telomerase activity in the cord blood cells from type 1 and gestational diabetes mellitus neonates, compared to the non-diabetic patients, in response to in utero oxidative DNA and telomere damage. In relation to obesity, a recent meta-analysis study found a tendency toward negative correlation (weak to moderate) between obesity and telomere length, with an important heterogeneity among the studies [49]. Furthermore, no association was detected between biomarkers of obesity/diabetes and short lymphocyte telomere length [50]. However, an increase in relative telomere length was observed 10 years after bariatric surgery, presumably due to the improvement of metabolic traits [46].

SIRT1, TP53 and BCL2 are genes involved in telomere-mitochondrial axis and apoptosis. In our present study, only BCL2 was downregulated in blood cells of GDM neonates and in obese adults. This finding suggests that hyperglycemia might be responsible for a dysregulation of the apoptotic process in umbilical blood, which is comprised mainly of immunological (lymphocytes and monocytes) and hematopoietic stem/progenitor cells [51]. In fact, maternal obesity has been associated with fetal immune system alterations [52,53]. High-fat diet administration during gestation and postnatally, alters the fetus lipid profile leading to an increased adipose tissue mass and TNF- $\alpha$ production, which, in turn, stimulates the synthesis of proinflammatory cytokines. In addition, decreased CD4 T cells and increased plasmacytoid dendritic cells, besides overproduction of IL-4, IL-6 and INFa-2, were observed in umbilical-cord blood cells of neonates of obese women [53]. This decrease in circulating CD4 T-cells may be indicative of dysregulated thymic output or increased peripheral CD4 T-cell death. However, the exactly mechanism is not fully understood [53]. Increased apoptosis rates of regulatory $\mathrm{T}$ cells (Tregs) induced by oxidative stress through changes in $B A X$, caspase 3 and $B C L 2$ gene expression were also recently described [54]. Additionally, a decreased percentage of Tregs was also correlated with increased adiposity, inflammation and insulin resistance in peripheral blood from obese subjects [55], whereas decreased BCL2 protein expression and a high apoptosis index have been detected in placentas of diabetic women, and were related to newborn weight deviations [56].

As mentioned previously, our results showed that no change in TP53 or SIRT1 expression was caused by the hyperglycemic intrauterine environment or obesity. These findings are consistent with those on the telomere length, considering the association between telomere dysfunction and p53 activation and the regulatory role of SIRT1 on p53 $[57,58]$. Sirt1 is an NAD +-dependent histone deacetylase that performs several biological functions in different tissues, including control of
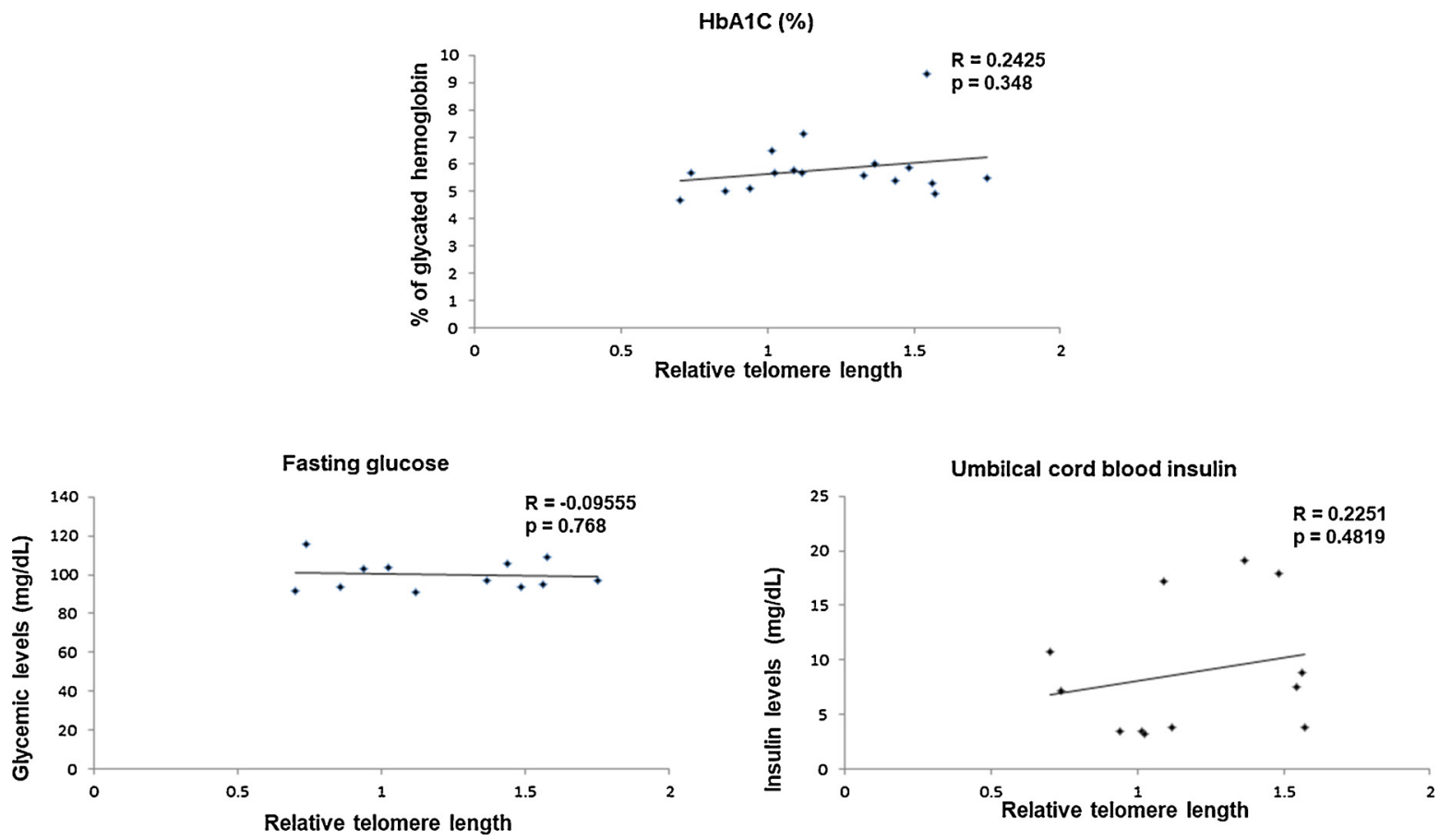

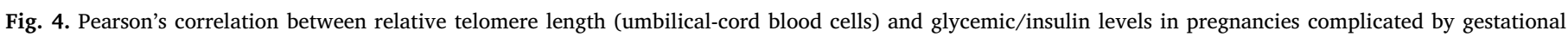

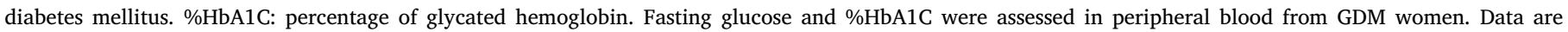
expressed as mean \pm standard deviation. 
fasting organ-energy metabolism and stress responses by regulating the acetylation of many intra-nuclear transcription factors [59]. It was demonstrated that SIRT1 overexpression can improve glucose metabolism and insulin signaling [60]. On the other hand, oxidative stress and hyperglycemia can decrease SIRT1 protein and gene expression in diabetic patients $[12,61]$. Nevertheless, our data showed no alteration in SIRT1 expression in placental or umbilical-cord blood cells. Perhaps the effective glycemic control demonstrated by the low percentage of glycated hemoglobin may have modulated SIRT1 mRNA levels, counteracting the downregulation promoted by the diabetic milieu. There are few data in the literature on TP53and GDM pregnancies, but a recent study demonstrated that GDM is able to dysregulate genes belonging to the p53 signaling pathway in omental visceral adipose tissue, thus leading to insulin resistance [62].

Our data also showed a downregulation of miR-181a in umbilicalcord blood cells from neonates of GDM women, which was not correlated with SIRT1 or BCL2 modulation.

Moreover, it has been suggested that miR-181a expression is increased as a feedback mechanism to attenuate the ox-LDL-stimulated immune inflammatory response by targeting c-Fos in dendritic cells, accompanied by increased expression of IL-10 and production of Tregs cells [63]. Since Tregs suppress inflammatory response promoted by effector $\mathrm{T}$ cells, their reduction may contribute to the pathogenesis of obesity-related inflammation [54]. Thus, downregulation of BCL2 and mir-181a in umbilical-cord blood cells from GDM neonates may be related to alterations in immune system cellularity and increased inflammatory processes. Since miRNAs can target multiple genes, and therefore the biological function of a single miRNA may be diverse, further studies are required to identify the target genes of miR-181a in umbilical-cord blood cells.

In conclusion, our study demonstrated that the GDM hyperglycemic intrauterine environment can promote transcriptional alterations in BCL2 and miR-181a in umbilical-cord blood cells of neonates. Furthermore, both GDM neonates and obese subjects share the same transcriptional alteration in $B C L 2$. Considering the relationship between obesity and the functions regulated by these two genes, BCL2 and miR-181a could be adopted as potential biomarkers for childhood obesity. However, further studies are recommended to confirm this hypothesis.

\section{Acknowledgements}

The authors are grateful to Immaculata De Vivo, Esther H. Orr and Patrice Soule (Department of Epidemiology, Harvard T.H. Chan School of Public Health) for technical contributions. This work was supported by the São Paulo Research Foundation (FAPESP; grant number 2012/ 19362-7). The sponsor have no involvement in the study design; collection, analysis and interpretation of data; the writing of the manuscript; the decision to submit the manuscript for publication.

\section{References}

[1] N. Ohtani, S. Yoshimoto, E. Hara, Obesity and cancer: a gut microbial connection, Cancer Res. 74 (2014) 1885-1889.

[2] World Health Organization (WHO), Obesity and Overweight, (2017) (Accessed 21 June17) [dataset], http://www.who.int/mediacentre/factsheets/fs311/en/.

[3] C.D. Fryar, M.D. Carroll, C.L. Ogden, Prevalence of Overweight and Obesity Among Children and Adolescents: United States, 1963-1965 Through 2011-2012, National Center for Health Statistics, 2014, https://www.cdc.gov/nchs/data/hestat/obesity child_11_12/obesity_child_11_12.pdf.

[4] L. Hiersch, Y. Yogev, Impact of gestational hyperglycemia on maternal and child health, Curr. Opin. Clin. Nutr. Metab. Care 17 (2014) 255-260, http://dx.doi.org/ 10.1097/MCO.0000000000000030.

[5] S.R. Wesolowski, K.C. Kasmi, K.R. Jonscher, J.E. Friedman, Developmental origins of NAFLD: a womb with a clue, Nat. Rev. Gastroenterol. Hepatol. 14 (2017) 81-96, http://dx.doi.org/10.1038/nrgastro.2016.160.

[6] J. Xu, J. Ye, Y. Wu, H. Zhang, Q. Luo, C. Han, X. Ye, H. Wang, J. He, H. Huang, Y. Liu, M. Dong, Reduced fetal telomere length in gestational diabetes, PLoS One 9 (2014) e86161, , http://dx.doi.org/10.1371/journal.pone.0086161.

[7] L.L. Wu, D.L. Russell, S.L. Wong, M. Chen, T.S. Tsai, J.C. St John, R.J. Norman,
M.A. Febbraio, J. Carroll, R.L. Robker, Mitochondrial dysfunction in oocytes of obese mothers: transmission to offspring and reversal by pharmacological endoplasmic reticulum stress inhibitors, Development 142 (2015) 681-691, http://dx. doi.org/10.1242/dev.114850.

[8] T. Biron-Shental, M. Liberman, M. Elbaz, I. Laish, R. Sharony, A. Amiel, Telomere homeostasis in placentas from pregnancies with uncontrolled diabetes, Placenta 44 (2016) 13-18, http://dx.doi.org/10.1016/j.placenta.2016.05.009.

[9] F. Giacco, M. Brownlee, Oxidative stress and diabetic complications, Circ. Res. 107 (2010) 1058-1070, http://dx.doi.org/10.1161/CIRCRESAHA.110.223545.

[10] X. Cheng, S.J. Chapple, B. Patel, W. Puszyk, D. Sugden, X. Yin, M. Mayr, R.C. Siow, G.E. Mann, Gestational diabetes mellitus impairs Nrf2-mediated adaptive antioxidant defenses and redox signaling in fetal endothelial cells in utero, Diabetes 62 (2013) 4088-4097, http://dx.doi.org/10.2337/db13-0169.

[11] J.A. Palacios, D. Herranz, M.L. De Bonis, S. Velasco, M. Serrano, M.A. Blasco, SIRT1 contributes to telomere maintenance and augments global homologous recombination, J. Cell. Biol. 191 (2010) 1299e.

[12] J. Gui, A. Potthast, A. Rohrbach, K. Borns, A.M. Das, F. von Versen-Höynck, Gestational diabetes induces alterations of sirtuins in fetal endothelial cells, Pediatr. Res. 79 (2016) 788-798, http://dx.doi.org/10.1038/pr.2015.269.

[13] J. Brenmoehl, A. Hoeflich, Dual control of mitochondrial biogenesis by Sirtuin 1 and Sirtuin 3, Mitochondrion 13 (2013) 755-761, http://dx.doi.org/10.1016/j. mito.2013.04.002.

[14] M.L. De Bonis, S. Ortega, M.A. Blasco, SIRT1 is necessary for proficient telomere elongation and genomic stability of induced pluripotent stem cells, Stem Cell Reports 2 (2014) 690-706, http://dx.doi.org/10.1016/j.stemcr.2014.03.002.

[15] S. Tutton, G.A. Azzam, N. Stong, O. Vladimirova, A. Wiedmer, J.A. Monteith, K. Beishline, Z. Wang, Z. Deng, H. Riethman, S.B. McMahon, M. Murphy, P.M. Lieberman, Subtelomeric p53 binding prevents accumulation of DNA damage at human telomeres, EMBO J. 35 (2016) 193-207, http://dx.doi.org/10.15252/ embj.201490880.

[16] W.M. Kamp, P.Y. Wang, P.M. Hwang, TP53 mutation, mitochondria and cancer, Curr. Opin. Genet. Dev. 38 (2016) 16-22, http://dx.doi.org/10.1016/j.gde.2016. 02.007.

[17] S.G. Rolland, B. Conradt, New role of the Bcl-2 family of proteins in the regulation of mitochondrial dynamics, Curr. Opin. Cell. Biol. 22 (2010) 852-858, http://dx. doi.org/10.1016/j.ceb.2010.07.014.

[18] M. Uraoka, K. Ikeda, R. Kurimoto-Nakano, Y. Nakagawa, M. Koide, Y. Akakabe, Y. Kitamura, T. Ueyama, S. Matoba, H. Yamada, M. Okigaki, H. Matsubara, Loss of BCL-2 during the senescence exacerbates the impaired angiogenic functions in endothelial cells by deteriorating the mitochondrial redox state, Hypertension 58 (2011) 254-263, http://dx.doi.org/10.1161/HYPERTENSIONAHA.111.176701.

[19] A. Salminen, K. Kaarniranta, A. Kauppinen, Beclin 1 interactome controls the crosstalk between apoptosis, autophagy and inflammasome activation: impact on the aging process, Ageing Res. Rev. 12 (2013) 520-534, http://dx.doi.org/10. 1016/j.arr.2012.11.004

[20] M. Aharoni-Simon, R. Shumiatcher, A. Yeung, A.Z. Shih, V.W. Dolinsky, C.A. Doucette, D.S. Luciani, Bcl-2 regulates reactive oxygen species signaling and a redox-sensitive mitochondrial proton leak in mouse pancreatic $\beta$-cells, Endocrinology 157 (2016) 2270-2281, http://dx.doi.org/10.1210/en.2015-1964.

[21] A. Gross, S.G. Katz, Non-apoptotic functions of Bcl-2 family proteins, Cell Death Differ. (2017) 1348-1358, http://dx.doi.org/10.1038/cdd.2017.22.

[22] C. Esau, C.S. Davis, S.F. Murray, X.X. Yu, S.K. Pandey, M. Pear, L. Watts, S.L. Booten, M. Graham, R. McKay, A. Subramaniam, S. Propp, B.A. Lollo, S. Freier, C.F. Bennett, S. Bhanot, B.P. Monia, miR-122 regulation of lipid metabolism revealed by in vivo antisense targeting, Cell. Metab. 3 (2006) 87-98.

[23] H.W. Hwang, J.T. Mendell, MicroRNAs in cell proliferation, cell death, and tumorigenesis, Br. J. Cancer 94 (2007) 776-780.

[24] N. Klöting, S. Berthold, P. Kovacs, M.R. Schön, M. Fasshauer, K. Ruschke, M. Stumvoll, M. Blüher, MicroRNA expression in human omental and subcutaneous adipose tissue, PLos One 4 (2009) e4699, http://dx.doi.org/10.1371/journal.pone. 0004699.

[25] M.R. Rippo, F. Olivieri, V. Monsurrò, F. Prattichizzo, M.C. Albertini, A.D. Procopio, MitomiRs in human inflamm-aging: a hypothesis involving miR-181a, miR-34a and miR-146a, Exp. Gerontol. 56 (2014) 154-163, http://dx.doi.org/10.1016/j.exger. 2014.03.002.

[26] A. Kurylowicz, M. Owczarz, J. Polosak, M.I. Jonas, W. Lisik, M. Jonas, A. Chmura, M. Puzianowska-Kuznicka, SIRT1 and SIRT7 expression in adipose tissues of obese and normal-weight individuals is regulated by microRNAs but not by methylation status, Int. J. Obes. 40 (2016) 1635-1642, http://dx.doi.org/10.1038/ijo.2016.131.

[27] B. Zhou, C. Li, W. Qi, Y. Zhang, F. Zhang, J.X. Wu, Y.N. Hu, D.M. Wu, Y. Liu, T.T. Yan, Q. Jing, M.F. Liu, Q.W. Zhai, Downregulation of miR-181a upregulates sirtuin-1 (SIRT1) and improves hepatic insulin sensitivity, Diabetologia 55 (2012) 2032-2043, http://dx.doi.org/10.1007/s00125-012-2539-8.

[28] American Diabetes Association (ADA), Standards of Medical Care in Diabetes 2017 (Accessed 13 April 2018), http://care.diabetesjournals.org/content/diacare/ suppl/2016/12/15/40.Supplement 1.DC1/DC 40 S1 final.pdf.

[29] M.V. Rudge, J.C. Peracoli, A.T. Berezowski, I.M. Calderon, M.A. Brasil, The oral glucose tolerance test is a poor predictor of hyperglycemia during pregnancy, Braz. J. Med. Biol. Res. 23 (1990) 1079-1089.

[30] F.C. Battaglia, L.O. Lubchenco, A practical classification of newborn infants by weight and gestational age, J. Pediatr. 71 (1967) 159-163.

[31] Centers for Disease Control and Prevention (CDC), Tobacco Control State Highlights 2012 (Accessed 04 January 2017), https://www.cdc.gov/tobacco/data_statistics/ state_data/state_highlights/2012/pdfs/introduction.pdf.

[32] A.M. Gontijo, J.P. Marcondes, F.N. Elias, M.L. de Oliveira, R.O. de Lima, D.M.F. Salvadori, J.L. de Camargo, DNA damage in cytologically normal urothelial 
cells of patients with a history of urothelial cell carcinoma, Environ. Mol. Mutagen. 40 (2002) 190-199.

[33] K.J. Livak, T.D. Schmittgen, Analysis of relative gene expression data using realtime quantitative PCR and the 2- $\triangle \Delta$ CT method, Methods 25 (2001) 402-408.

[34] R.M. Cawthon, Telomere measurement by quantitative PCR, Nucleic Acids Res. 30 (2002) e47.

[35] D.J. Barker, Intrauterine programming of adult disease, Mol. Med. Today 1 (1995) 418-423.

[36] M. Desai, M. Beall, M.G. Ross, Developmental origins of obesity: programmed adipogenesis, Curr. Diab. Rep. 13 (2013) 27-33, http://dx.doi.org/10.1007/ s11892-012-0344-x.

[37] C. Durnwald, M. Landon, Fetal links to chronic disease: the role of gestational diabetes mellitus, Am. J. Perinatol. 30 (2013) 343-346, http://dx.doi.org/10.1055/ s-0032-1324707.

[38] G. Desoye, M. Gauster, C. Wadsack, Placental transport in pregnancy pathologies, Am. J. Clin. Nutr. 94 (2011) 1896S-1902S, http://dx.doi.org/10.3945/ajcn.110. 000851.

[39] A. Vambergue, I. Fajardy, Consequences of gestational and pregestational diabetes on placental function and birth weight, World J. Diabetes 2 (2011) 196-203, http://dx.doi.org/10.4239/wjd.v2.i11.196.

[40] M. Horikoshi, R.N. Beaumont, F.R. Day, N.M. Warrington, M.N. Kooijman, J. Fernandez-Tajes, B. Feenstra, N.R. van Zuydam, K.J. Gaulton, N. Grarup, J.P. Bradfield, D.P. Strachan, R. Li-Gao, T.S. Ahluwalia, E. Kreiner, R. Rueedi, L.P. Lyytikäinen, D.L. Cousminer, Y. Wu, E. Thiering, C.A. Wang, C.T. Have, J.J. Hottenga, N. Vilor-Tejedor, P.K. Joshi, E.T.H. Boh, I. Ntalla, N. Pitkänen, A. Mahajan, E.M. van Leeuwen, R. Joro, V. Lagou, M. Nodzenski, L.A. Diver, K.T. Zondervan, M. Bustamante, P. Marques-Vidal, J.M. Mercader, A.J. Bennett, N. Rahmioglu, D.R. Nyholt, R.C.W. Ma, C.H.T. Tam, W.H. Tam, CHARGE Consortium Hematology, Working Group, S.K. Ganesh, F.J. van Rooij, S.E. Jones, P.R. Loh, K.S. Ruth, M.A. Tuke, J. Tyrrel, A.R. Wood, H. Yaghootkar, D.M. Scholtens, L. Paternoster, I. Prokopenko, P. Kovacs, M. Atalay, S.M. Willems, K. Panoutsopoulou, X. Wang, L. Carstensen, F. Geller, K.E. Schraut, M. Murcia, C.E. van Beijsterveldt, G. Willemsen, E.V.R. Appel, C.E. Fonvig, C. Trier, C.M. Tiesler, M. Standl, Z. Kutalik, S. Bonas-Guarch, D.M. Hougaard, F. Sánchez, D. Torrents, J. Waage, M.V. Hollegaard, H.G. de Haan, F.R. Rosendaal, C. MedinaGomez, S.M. Ring, G. Hemani, G. McMahon, N.R. Robertson, C.J. Groves, C. Langenberg, J. Luan, R.A. Scott, J.H. Zhao, F.D. Mentch, S.M. MacKenzie, R.M. Reynolds, W.L. Lowe Jr., A. Tönjes, M. Stumvoll, V. Lindi, T.A. Lakka, C.M. van Duijn, W. Kiess, A. Körner, T.I. Sørensen, H. Niinikoski, K. Pahkala, O.T. Raitakari, E. Zeggini, G.V. Dedoussis, Y.Y. Teo, S.M. Saw, M. Melbye, H. Campbell, J.F. Wilson, M. Vrijheid, E.J. de Geus, D.I. Boomsma, H.N. Kadarmideen, J.C. Holm, T. Hansen, S. Sebert, A.T. Hattersley, L.J. Beilin, J.P. Newnham, C.E. Pennell, L. Heinrich, L.S. Adair, J.B. Borja, K.L. Mohlke, J.G. Eriksson, E.E. Widén, M. Kähönen, J.S. Viikari, T. Lehtimäki, P. Vollenweider, K. Bønnelykke, H. Bisgaard, D.O. Mook-Kanamori, A. Hofman, F. Rivadeneira, A.G. Uitterlinden, C. Pisinger, O. Pedersen, C. Power, E. Hyppönen, N.J. Wareham, H. Hakonarson, E. Davies, B.R. Walker, V.W. Jaddoe, M.R. Jarvelin, S.F. Grant, A.A. Vaag, D.A. Lawlor, T.M. Frayling, G. Davey Smith, A.P. Morris, K.K. Ong, J.F. Felix, N.J. Timpson, J.R. Perry, D.M. Evans, M.I. McCarthy, R.M. Freathy, Genome-wide associations for birth weight and correlations with adult disease, Nature 538 (2016) 248-252, http://dx.doi.org/10.1038/nature19806.

[41] J.A. Lavery, A.M. Friedman, K.M. Keyes, J.D. Wright, C.V. Ananth, Gestational diabetes in the United States: temporal changes in prevalence rates between 1979 and 2010, BJOG 124 (2017) 804-813, http://dx.doi.org/10.1111/1471-0528. 14236.

[42] E. Oken, M.W. Gillman, Fetal origins of obesity, Obes. Res. 11 (2003) 496-506.

[43] S. Gu, X. An, L. Fang, X. Zhang, C. Zhang, J. Wang, Q. Liu, Y. Zhang, Y. Wei, Z. Hu, F. Chen, H. Shen, Risk factors and long-term health consequences of macrosomia: a prospective study in Jiangsu Province, China, J. Biomed. Res. 26 (2012) 235-240, http://dx.doi.org/10.7555/JBR.26.20120037.

[44] M.B. Landon, M.M. Rice, M.W. Varner, B.M. Casey, U.M. Reddy, R.J. Wapner, D.J. Rouse, J.R. Biggio Jr., J.M. Thorp, E.K. Chien, G. Saade, A.M. Peaceman, S.C. Blackwell, J.P. VanDorsten, Eunice Kennedy Shriver National Institute of Child Health, Human Development Maternal-Fetal Medicine Units (MFMU) Network, mild gestational diabetes mellitus and long-term child health, Diabetes Care 38 (2015) 445-452, http://dx.doi.org/10.2337/dc14-2159.

[45] L. Guillemette, A. Durksen, R. Rabbani, R. Zarychanski, A.M. Abou-Setta, T.A. Duhamel, J.M. McGavock, B. Wicklow, Intensive gestational glycemic management and childhood obesity: a systematic review and meta-analysis, Int. J. Obes. (Lond.) 41 (2017) 999-1004, http://dx.doi.org/10.1038/ijo.2017.65.

[46] M. Laimer, A. Melmer, C. Lamina, J. Raschenberger, P. Adamovski, J. Engl, C. Ress,
A. Tschoner, C. Gelsinger, L. Mair, S. Kiechl, J. Willeit, P. Willeit, C. Stettler, H. Tilg, F. Kronenberg, C. Ebenbichler, Telomere length increase after weight loss induced by bariatric surgery: results from a 10 year prospective study, Int. J. Obes. 40 (2016) 773-778, http://dx.doi.org/10.1038/ijo.2015.238.

[47] C. Gilfillan, P. Naidu, F. Gunawan, F. Hassan, P. Tian, N. Elwood, Leukocyte telomere length in the neonatal offspring of mothers with gestational and pre-gestational diabetes, PLoS One 11 (2016) e0163824, , http://dx.doi.org/10.1371/ journal.pone.0163824.

[48] J.A. Cross, R.C. Temple, J.C. Hughes, N.C. Dozio, C. Brennan, K. Stanley, H.R. Murphy, D. Fowler, D.A. Hughes, M.J. Sampson, Cord blood telomere length, telomerase activity and inflammatory markers in pregnancies in women with diabetes or gestational diabetes, Diabet. Med. 27 (2010) 1264-1270.

[49] E. Mundstock, E.E. Sarria, H. Zatti, F. Mattos Louzada, L. KichGrun, M. Herbert Jones, F.T. Guma, J. Mazzola, M. Epifanio, R.T. Stein, F.M. Barbé-Tuana, R. Mattiello, Effect of obesity on telomere length: systematic review and metaanalysis, Obesity 23 (2015) 2165-2174, http://dx.doi.org/10.1002/oby.21183.

[50] S. Hardikar, X. Song, R.A. Risques, T.J. Montine, C. Duggan, P.L. Blount, B.J. Reid, G.L. Anderson, M. Kratz, E. White, T.L. Vaughan, Obesity and inflammation markers in relation to leukocyte telomere length in a cross-sectional study of persons with Barrett's esophagus, BMC Obes. 2 (2015) 32, http://dx.doi.org/10.1186/ s40608-015-0063-3.

[51] J.D. Newcomb, P.R. Sanberg, S.K. Klasko, A.E. Willing, Umbilical cord blood research: current and future perspectives, Cell Transplant 16 (2007) 151-158.

[52] Y. Odaka, M. Nakano, T. Tanaka, T. Kaburagi, H. Yoshino, N. Sato-Mito, K. Sato The influence of a high-fat dietary environment in the fetal period on postnatal metabolic and immune function, Obesity 18 (2010) 1688-1694, http://dx.doi.org/ 10.1038/oby.2009.513.

[53] R.M. Wilson, N.E. Marshall, D.R. Jeske, J.Q. Purnell, K. Thornburg, I. Messaoudi, Maternal obesity alters immune cell frequencies and responses in umbilical cord blood samples, Pediatr. Allergy Immunol. 26 (2015) 344-351, http://dx.doi.org/ 10.1111/pai.12387.

[54] B. Wang, J. Sun, Y. Ma, G. Wu, Y. Shi, G. Le, Increased oxidative stress and the apoptosis of regulatory $\mathrm{T}$ cells in obese mice but not resistant mice in response to a high-fat diet, Cell Immunol. 288 (2014) 39-46, http://dx.doi.org/10.1016/j. cellimm.2014.02.003.

[55] N.M. Wagner, G. Brandhorst, F. Czepluch, M. Lankeit, C. Eberle, S. Herzberg, V. Faustin, J. Riggert, M. Oellerich, G. Hasenfuss, S. Konstantinides, K. Schäfer, Circulating regulatory $\mathrm{T}$ cells are reduced in obesity and may identify subjects at increased metabolic and cardiovascular risk, Obesity 21 (2013) 461-468, http://dx doi.org/10.1002/oby.20087.

[56] F. Sgarbosa, L.F. Barbisan, M.A. Brasil, E. Costa, I.M. Calderon, C.R. Gonçalves, E. Bevilacqua, M.V. Rudge, Changes in apoptosis and Bcl-2 expression in human hyperglycemic, term placental trophoblast, Diabetes Res. Clin. Pract. 73 (2006) 143-149.

[57] E. Sahin, S. Colla, M. Liesa, J. Moslehi, F.L. Müller, M. Guo, M. Cooper, D. Kotton, A.J. Fabian, C. Walkey, R.S. Maser, G. Tonon, F. Foerster, R. Xiong, Y.A. Wang, S.A. Shukla, M. Jaskelioff, E.S. Martin, T.P. Heffernan, A. Protopopov, E. Ivanova, J.E. Mahoney, M. Kost-Alimova, S.R. Perry, R. Bronson, R. Liao, R. Mulligan, O.S. Shirihai, L. Chin, R.A. DePinho, Telomere dysfunction induces metabolic and mitochondrial compromise, Nature 470 (2011) 359-365, http://dx.doi.org/10. 1038/nature09787.

[58] J.A. Baur, Z. Ungvari, R.K. Minor, D.G. Le Couteur, de Cabo R, Are sirtuins viable targets for improving healthspan and lifespan? Nat. Rev. Drug Discov. 11 (2012) 443-461, http://dx.doi.org/10.1038/nrd3738.

[59] F. Liang, S. Kume, D. Koya, SIRT1 and insulin resistance, Nat. Rev. Endocrinol. 5 (2009) 367-373, http://dx.doi.org/10.1038/nrendo.2009.101.

[60] S. Chen, Z. Zhao, L. Ke, Z. Li, W. Li, Z. Zhang, Y. Zhou, X. Feng, W. Zhu, Resveratrol improves glucose uptake in insulin-resistant adipocytes via Sirt1, J. Nutr. Biochem. 55 (2018) 209-218, http://dx.doi.org/10.1016/j.jnutbio.2018.02.007.

[61] M. Lappas, S. Andrikopoulos, M. Permezel, Hypoxanthine-xanthine oxidase downregulates GLUT1 transcription via SIRT1 resulting in decreased glucose uptake in human placenta, J. Endocrinol. 213 (2012) 49-57, http://dx.doi.org/10.1530/JOE11-0355.

[62] Y. Qian, H. Sun, H. Xiao, M. Ma, X. Xiao, Q. Qu, Microarray analysis of differentially expressed genes and their functions in omental visceral adipose tissues of pregnant women with vs. without gestational diabetes mellitus, Biomed. Rep. 6 (2017) 503-512, http://dx.doi.org/10.3892/br.2017.878.

[63] C. Wu, Y. Gong, J. Yuan, W. Zhang, G. Zhao, H. Li, A. Sun, Hu Kai, Y. Zou, J. Ge, MicroRNA-181a represses ox-LDL-stimulated inflammatory response in dendritic cell by targeting c-Fos, J. Lipid Res. 53 (2012) 2355-2363, http://dx.doi.org/10 1194/jlr.M028878. 